\title{
Bagasse Cogeneration in India: Status, Barriers
}

\author{
Mukesh Kumar Mishra ${ }^{1}$, Dr. Nilay Khare ${ }^{2}$, Dr. Alka Bani Agrawal ${ }^{3}$ \\ ${ }^{1}$ Senior Lecturer, Department of Mechanical Engg., S.V. Polytechnic College, Bhopal, M.P., India \\ ${ }^{2}$ Professor, Department of CSE, MANIT, Bhopal, M.P., India \\ ${ }^{3}$ Professor, Department of Mechanical Engg, UIT (RGPV) Bhopal, M.P., India
}

\begin{abstract}
India is one of the largest consumers and producers of sugar in the world and is the world's second largest producer next to Brazil of the sugarcane. Country has made impressive growth in the bagasse cogeneration. However, sustaining the growth is the real challenge. This article provides an overview of the current status, historical growth, technological status, policy, regulatory and fiscal support extended by the Govt of India as well as state governments to bagasse cogeneration. This work has identified the barriers in speedy adoption of the technology by sugar mills. The article concludes that support extended to bagasse cogeneration by the MNRE, especially to cooperative sugar mills, must be continued. The preferential tariff determined by CERC and SERCs for the bagasse cogeneration must take into account the increased support price offered to sugarcane by state governments as well as price offered to bagasse by competing technologies like paper and pulp industries. Strong RPO compliance by power distribution companies and streamlining of REC mechanism is required to attract industries, project developers and investors to invest in renewable energy in the country.
\end{abstract}

Key Words: Bagasse Cogeneration, Barriers, Cogeneration Status, India, Sugar Mills.

\section{Introduction}

Meeting electricity demand in sustainable manner is one of the major challenges that India is facing. As per Integrated Energy Policy of GOI, electricity generation capacity must be increased to nearly $800000 \mathrm{MW}$ from current generation capacity of 2, 25,793 MW by 2032[1]. This huge capacity addition is big challenge for the country. At present electricity generation in India is dominated by the coal which is a major source of carbon emission. Further, depletion of fossil fuel and increased import of energy resources is a matter of concern in India. In view of this, country has launched a programme to enhance proportion of renewable energy in the electricity mix. MNRE has adopted strategic plan for new and renewable energy sector for the period 201117 [2]. Further, $15600 \mathrm{MW}$ of renewable energy capacity was added during $11^{\text {th }}$ plan (2007-12) against a target of $12280 \mathrm{MW}$ [3].

India is one of the largest consumers and producers of sugar in the world and is the world's second largest producer next to Brazil of the sugarcane. Sugar production is an energy intensive industry and requires both steam as well as electricity. Bagasse is the leftover of the sugarcane after crushing and is burnt as a fuel in the boiler of sugar mill. Bagasse cogeneration has been practiced in sugar mills since long to meet sugar mills own energy needs. However, supplying excess electricity to the grid has gained momentum worldwide in last one decade. It offers several advantages such as near - zero fuel cost, increased viability of sugar mills, energy security, fuel diversity, reduced transmission and distribution losses and carbon emission reduction. In view of this, GOI has launched a programme to enhance surplus electricity generation from bagasse cogeneration. Bagasse cogeneration is renewable energy and comes under Ministry for New and Renewable Sources of Energy of Govt of India.

Bagasse-based cogeneration potential in sugar mills is estimated to be 5000MW [4]. Further, as per KPMG analysis this potential will be approximately 9700 MW by 2017[5].As per MNRE database total installed capacity of bagasse cogeneration is $2393 \mathrm{MW}$ as on $31^{\text {st }}$ October 2013 [6]. It is estimated that four million units of electricity per megawatt of capacity of the cogeneration plant is generated per year [7]. Objective of this study is to provide an account of bagasse cogeneration in India and to indentify the barriers in the fast deployment of the technology. 


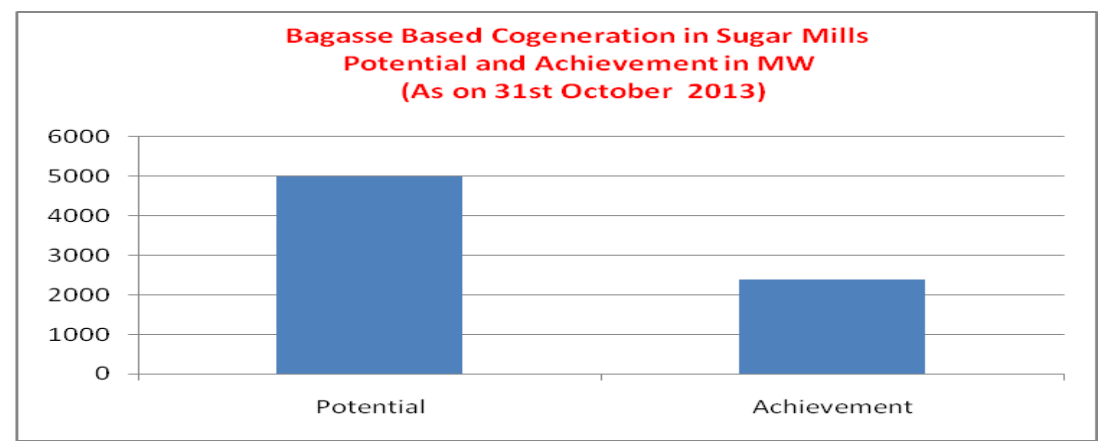

Figure 1: Bagasse Cogeneration Potential and Achievement

This subject has gained considerable attention of the scholars, industries, government departments and NGOs. World Alliance for Decentralized Energy (WADE) conducted a major study in 2004 in which global potential of bagasse cogeneration was reviewed[8]. India, being the sugar giant, was widely covered in the study. Malini Ranganathan studied the bagasse cogeneration in her MS Thesis titled "Can Co-ops Become Energy Producers Too? Challenges and Prospects for Efficient Co-generation in India's Co-operative Sugar Sector" at Energy and Resources Group of the University of California, Berkeley in 2005[9]. UNDP and GOI prepared a project document titled "Removal of Barriers to Biomass Power Generation in India, Phase I" under Global Environment Facility Program in 2005[10]. Barbara Haya et al published a research paper "Barriers to sugar mill Cogeneration in India: Insights into the structure of post-2012 climate financing instruments" Climate and Development Journal in 2009[11].

Higher rate of deployment of bagasse cogeneration in India during last five years is noteworthy. In the eleventh five year plan (2012-2017) 1369.7 MW of electricity against target of $1200 \mathrm{MW}$ was added[3]. Further, during last 3 years $1000 \mathrm{MW}$ of the capacity has been added [07]. Authors have not come across any major study on bagasse cogeneration in India during last three years. Objective of this study is to fill this gap and provide an account of bagasse cogeneration in India and to indentify the barriers in the fast deployment of technology.

The following section of this article provides overview of sugar industry in India. We then describe potential and achievements in bagasse cogeneration so far in the country. This is followed by a description of the technology status of the bagasse cogeneration. We then review the policy, regulatory and fiscal support extended by the government to bagasse cogeneration. This is followed by a detailed analysis of barriers that the sector is facing. A comprehensive list of the organisations and associations related to sugar sector in India has been provided, before concluding the article, to interested readers to gain further insight in the subject.

Table 1: Nomenclature

\begin{tabular}{|lll|}
\hline CERC & $:$ & Central Electricity Regulatory Commission \\
CFA & $:$ & Central Financial Assistance \\
FRP & $:$ & Fair and Remunerative Price \\
GOI & $:$ & Government of India \\
MNRE $:$ & Ministry for New and Renewable Sources of Energy \\
MNSE : & Ministry of Non Conventional Sources of Energy \\
NAPCC: & National Action Plan on Climate Change \\
RPO : & Renewable Purchase Obligation \\
SERC $:$ & State Electricity Regulatory Commission \\
TCD $:$ & Ton Crushing Capacity per Day \\
UNDP $:$ & United Nation Development Program \\
\hline
\end{tabular}

\section{Overview of India's sugar sector}

Sugar industry in India after textile is the second largest agriculture based industry. First sugar mill in India was established in 1930. Currently about 4 million hectares of land in India is under sugarcane with an average yield of 70 tons per hectare. Sugar industry in India is concentrated in states of Uttar Pradesh, Maharashtra, Tamil Nadu, Karnataka, Andhra Pradesh, Gujarat, Haryana and Punjab. Growth of the sugar industry in India is described below in table[12] 
Table 2: Growth of the sugar industry in India

\begin{tabular}{|c|c|c|c|c|c|}
\hline Particulars & 2008-09 & $2009-10$ & $2010-11$ & $2011-12$ & $2012-13$ \\
\hline $\begin{array}{l}\text { Molasses Production } \\
\text { (Thousands Tons) }\end{array}$ & 6542 & 8400 & 10970 & 11824 & 11744 \\
\hline
\end{tabular}

The sugar sector is an important pillar of the Indian economy as it provides livelihood to 50 million farmers and to 5 million workers directly employed in sugar factory [13]. Besides this it creates employment in ancillary services in transportation and trade etc. At present sugar sector's output worth is Rs.80, 000 crore.

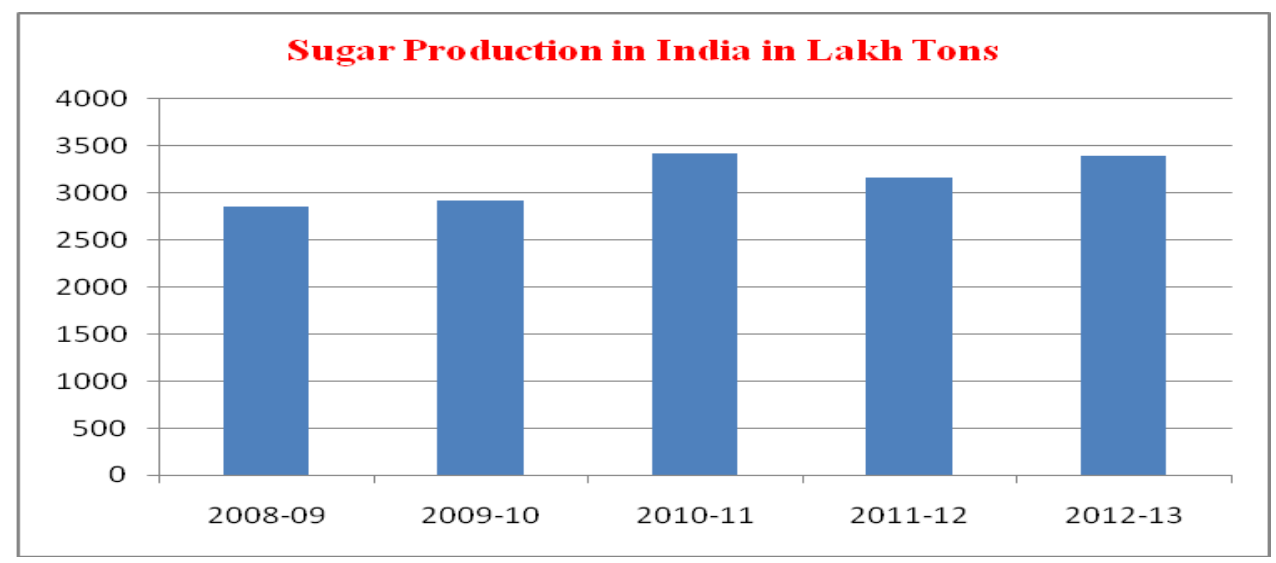

Figure 2: Sugar Production in India

Map of sugarcane production in India is given below [14].

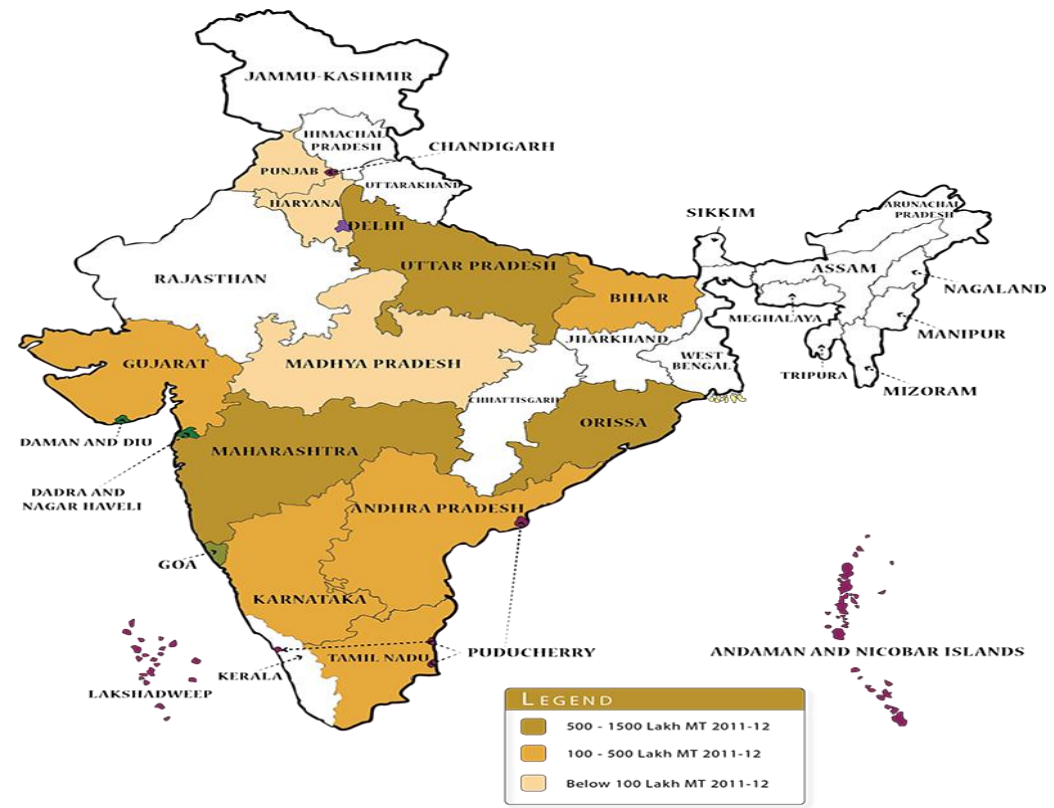

Figure 3: Map of sugarcane production in India

Sugar production in India has a typical of 3-4 year cycle [15]. Sugar cycle has been explained with the help of causal loop diagram. A positive causal link means the two nodes change in the same direction while a negative causal link means the two nodes change in opposite directions. For example link from sugar production to sugar availability is positive. So, sugar availability will increase with increase in sugar production and vice versa. Similarly link from sugar availability to sugar price is negative means sugar price will decrease with increase in sugar availability and vice versa. 


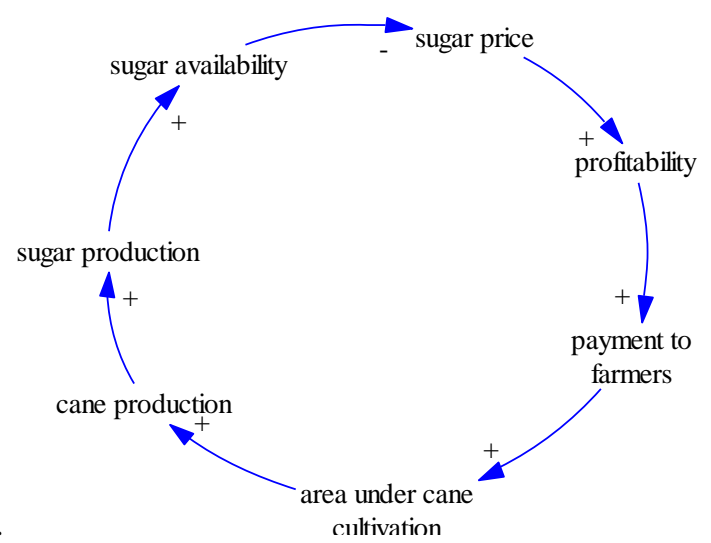

Figure 4: Causal Loop Diagram of Sugar Cycle in India

Higher sugar price results in increased profit in sugar industry and higher payment made to farmers. This motivates farmers to cultivate sugarcane in larger area causing an overproduction of sugarcane and sugar resulting in decrease in sugar price and profit and lower sugarcane price. Taking into account the lower prices for cane, the farmers switch back to other crops which results in low sugarcane production, low sugar production and higher sugar price.

Sugar mills in India are heterogeneous in terms of ownership, technology, size etc. Based on ownership structure mills can be classified into three categories- private mills, public mills and cooperative mills. Details of sugar mills in India including closed sugar mills as on 30.11.2012 is given below [13].

Table 3: Sugar mills in India including closed sugar mills as on 30.11.2012

\begin{tabular}{|c|c|c|}
\hline S.No. & Sector & Potential \\
\hline 1 & Private & 298 \\
\hline 2 & Public & 062 \\
\hline 3 & Cooperatives & 324 \\
\hline & Total & 684 \\
\hline
\end{tabular}

The mills have crushing capacity to produce around 300 lakh MT of sugar. The capacity is roughly distributed equally between private sector units and co-operative sector units. The capacity of sugar mills is in the range of 2500 TCD - 5000 TCD but increasingly expanding and going even beyond 10000 TCD.

De licensing of sugar sector in the year 1999 gave impetus to the growth of the sector and proportion of the sugar produced from private sector mills compared to cooperative and public sector mills increased after de licensing. However, sugar industry in India is still controlled through various regulations. Sector is facing significant challenges in ensuring farmer's profitability, mill profitability and availability of sugar to consumers at affordable price with cyclic nature of sugarcane production and sugar price. Pricing of the sugarcane is highly complex. Though GOI announce Fair and Remunerative Price (FRP) every year, state government has liberty to decide their support price. Sugar cane price varies across the sugar producing states.

\section{Potential and Achievement in Bagasse Cogeneration}

Cogeneration is defined as simultaneous generation of electricity and thermal power. Cogeneration in sugar mills have been explained by schematic diagram below:

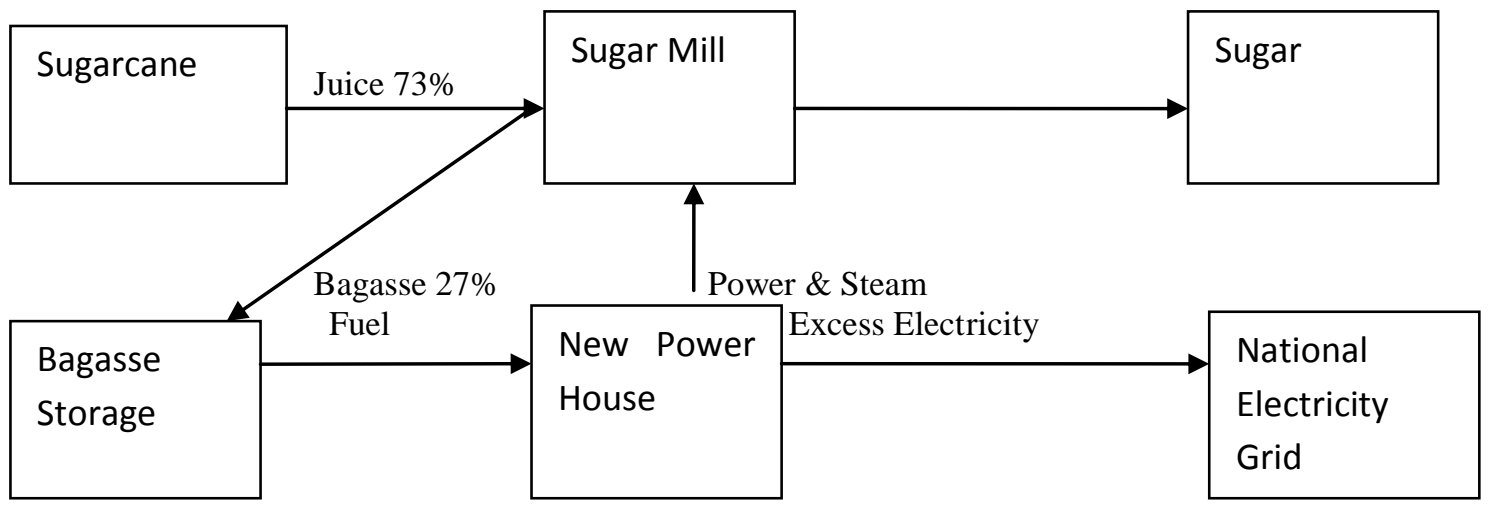

Figure 5: Schematic diagram of power cogeneration in sugar mills 
During sugar production season electricity generated from the plant is used for the production process and surplus is fed into grid while during off season all electricity generated is fed into grid.Cogeneration is not new to sugar industry in India. However grid connected surplus power generation from sugar industries gained momentum in India in 1993 consequent to a report submitted by a committee constituted by MNSE (Now known as MNRE). Bagasse cogeneration is a now a well understood and matured technology in the country. In the eleventh five year plan (2007-2012) 1369.7 MW of electricity against target of $1200 \mathrm{MW}$ has been added from bagasse cogeneration [16]. State wise status of bagasse cogeneration in India as on 31.03.2013 is given below in table [07].

Table 4: Status of bagasse cogeneration in India as on 31.03.2013

\begin{tabular}{|c|c|c|c|c|c|}
\hline S.No. & State & Potential & No of Projects & Installed capacity & \% Utilization \\
\hline 1 & Andhra Pradesh & 300 & 22 & 163.05 & 54.35 \\
\hline 2 & Bihar & 300 & 4 & 43.30 & 14.43 \\
\hline 3 & Gujrat & 350 & 0 & 00.00 & 00.00 \\
\hline 4 & Haryana & 350 & 4 & 31.80 & 9.09 \\
\hline 5 & Karnataka & 450 & 32 & 403.88 & 89.75 \\
\hline 6 & Maharashtra & 1250 & 65 & 580.90 & 46.47 \\
\hline 7 & Punjab & 300 & 6 & 62.00 & 20.67 \\
\hline 8 & Tamil Nadu & 450 & 26 & 327.00 & 72.67 \\
\hline 9 & Uttar Pradesh & 1250 & 53 & 710.50 & 56.8 \\
\hline \multirow[t]{2}{*}{10} & Uttarakhand & & 1 & 10.00 & \\
\hline & Total & 5000 & 213 & 2332.43 & 46.64 \\
\hline
\end{tabular}

Above table indicates that more than $50 \%$ of bagasse cogeneration potential is still untapped.

Major cogeneration plants in India are given below in table [17].

Table 5: Major cogeneration plants in India

\begin{tabular}{|c|l|c|}
\hline S.No. & Sugar Mill & Cogeneration Capacity in MW \\
\hline 1. & Dhampur Sugar Mills Ltd., Dhampur, Bijnor & 60.00 \\
\hline 2 & $\begin{array}{l}\text { Empee Sugars \& Chemicals Ltd., Edaikal, Ambasamudram, } \\
\text { Tirunelveli }\end{array}$ & 50.00 \\
\hline 3. & DSM Sugar, Asmoli, Moradabad & 40.00 \\
\hline 4. & Shree Ambika Sugars Ltd., Eraiyur, Titagudi, Cuddalore & 40.00 \\
\hline $\mathbf{5 .}$ & Trident Sugars Ltd., Madhunagar, Zaheerabad, Medak & 30.00 \\
\hline 6. & Triveni Engg. \& Ind. Ltd., Khatauli, Muzaffarnagar & 37.00 \\
\hline $\mathbf{7 .}$ & Sakthi Sugar Ltd., Padmathur, Jothinagar, Sivganga & 35.10 \\
\hline 8. & A. B. Sugars Ltd., Randhawa, Dasuya, Hoshiarpur & 33.00 \\
\hline 9. & $\begin{array}{l}\text { Sahakar Maharshi Shankarrao Mohite Patil SSK Ltd., Akluj, } \\
\text { Malshiras, Solapur }\end{array}$ & 33.00 \\
\hline $\mathbf{1 0}$ & Nirani Sugars Ltd., Mudhol, Bagalkot & 32.00 \\
\hline
\end{tabular}

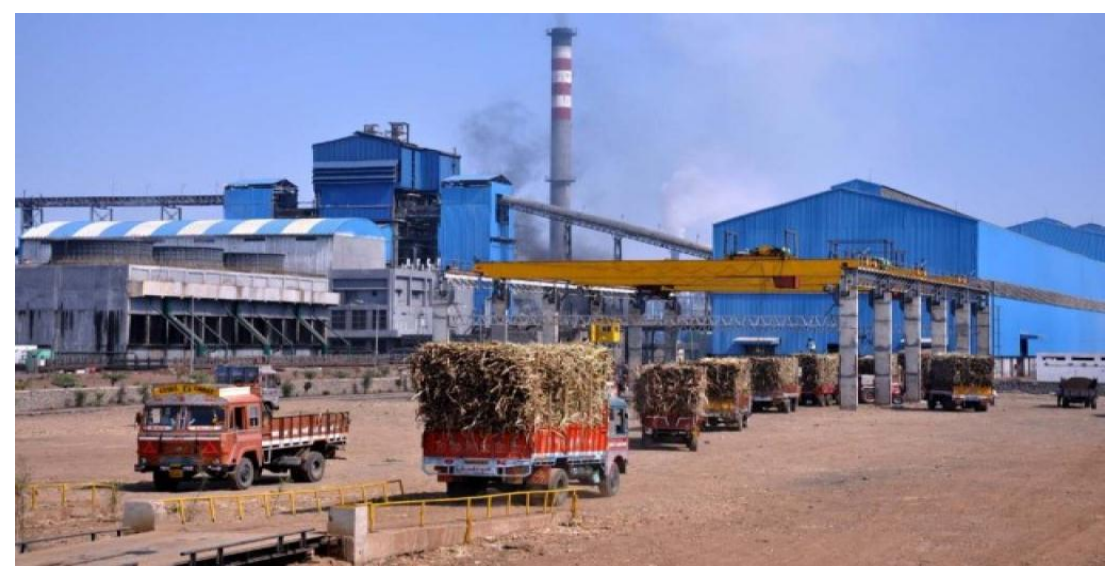

Figure 6: 30 MW Bagasse Cogeneration Project at a Sugar Mill in Maharashtra [18]

\section{Technological Status}

Power output from bagasse cogeneration mainly depends on two factors moisture content and technology used. Cogeneration plant works on traditional Rankine Cycle. Sugar production requires large quantity of processing steam at about 2.5 bar which is lower than that required for power generation. Therefore, 
steam at higher pressure and temperature must be generated to increase the efficiency of Rankine cycle. Hence in cogeneration projects high-pressure boiler configurations of 67 bar or 87 bar or 105 bar are used against the conventional 32 bar or 42 bar pressure boilers used in the sugar mill. Higher pressure and temperature are critical for increasing the cycle efficiency and power output. Cogeneration plant based on 105 bar and $520^{\circ} \mathrm{C}$ adopted in the state of Tamil Nadu and Andhra Pradesh generate about $6 \%$ more power than 87 bar and $515^{\circ} \mathrm{C}$ [19].

Manufacturing capability exists in the country for the equipment/machinery required for setting up cogeneration projects. Capability exists in the country for manufacturing spreader stoker fired, travelling grate/dumping grate boilers; atmospheric pressure fluidized bed boilers and circulating fluidized bed boilers. Manufacturers are further upgrading capabilities for high efficiency boilers. Manufacturing capability exists in the country for condensing, single extraction/double extraction condensing; back pressure turbines with the efficiencies comparable to the best in the world [18]. Except for some critical control equipment, most of the equipments can be procured from indigenous sources. Extra high pressure boilers have also been commercialized in India [20].

\section{Policy, Regulatory and Fiscal Support}

Renewable energy has gained considerable attention in India due to increasing energy demand, depletion of fossil fuel, carbon emission from burning of fossil fuel, increasing energy import bill. Bagasse cogeneration is considered renewable energy because $\mathrm{CO} 2$ equivalent to carbon emission during burning of bagasse is presumed to be absorbed during sugarcane production by farmers.GOI took several steps at policy, regulatory and fiscal level to promote bagasse cogeneration. First sugar mill in India was established in 1930. As stated earlier, MNSE took initiative in 1993 by constituting a committee to look prospect and promotion of bagasse cogeneration across Indian sugar mills.

The electricity act 2003 is the milestone of electricity reforms in India [21]. The act gave impetus to speedy diffusion of renewable energy by mandating the states to promote electricity generation from renewable energy. Provisions 86(1) (e) of EA 2003 mandates the states to "promote cogeneration and generation of electricity from renewable sources of energy by providing suitable measures for connectivity with the grid and sale of electricity to any person, and also specify, for purchase of electricity from such sources, a percentage of the total consumption of electricity in the area of a distribution licence ". Amount of power which must be purchased from renewable energy sources by DISCOMs is known as RPO. Further, electricity policy 2006 mandated the premium tariff to be fixed by SERCs and CERC for the renewable energy. Para 6.4 of the Tariff Policy stipulates "Pursuant to provisions of 86(1) (e) of EA 2003, Appropriate Commission shall fix minimum percentage for purchase of power from RE sources in the region and its impact on retail tariffs" [22].

India has implemented National Action Plan on Climate Change (NAPCC) released by Prime Minister of India in 2008. One of the important measures envisaged in the plan to deal with climate change is to enhance proportion of renewable energy into electricity generation. Total renewable energy electricity installed capacity targeted in the plan was 5\% in 2010 and $1 \%$ increase every year upto 2020 . Thus total planned installed capacity would be $15 \%$ by $2020[23]$.

Renewable energy resources are not evenly spread across India. Further, few states rich in renewable energy have exhausted their potential. Therefore the Renewable Energy Certificate Mechanism (REC) was adopted in India in 2010 to enable interstate sale and purchase of electrify produced from renewable sources of energy. The mechanism is intended to all states of India achieve RPO [24].

One of the thrust areas of electricity reforms initiated by Electricity Act 2003 is to open the electricity sector and introduce competition in all areas of electricity sector i.e. generation, transmission and distribution with the objective to increase the overall efficiency of the sector. At present, India is adopting cost plus approach for tariff determination in which tariff is fixed by regulatory commissions on the basis of actual cost involved in generation, transmission and distribution. India plans to switch over from cost plus approach to competitive bidding for electricity tariff determination. MNRE introduced the competitive bidding in selected projects in2013 [25]. 
The Chronology of events in bagsasse cogeneration has been described below by line diagram [08].

First Sugar Mill 1930

National programme on promotion of biomass power / bagasse based cogeneration 1992

De-licensing of sugar mills 1998

14 States announce Power purchase policies $\quad$ 1998-1999

Power sector reform slows project commissioning 2001-2003

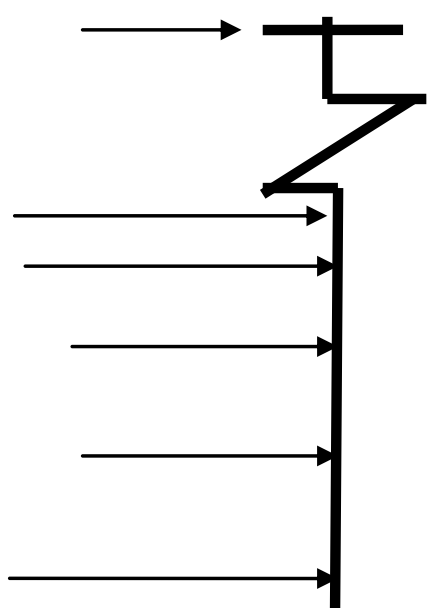

Some states go back on purchase Policies 2000-2003

Maharashtra Electricity Regulatory Commission issues incentive tariffs for the buy-back of electricity from bagasse $\mathbf{2 0 0 2}$

Electricity Act $\mathbf{2 0 0 3}$

Tariff Policy 2006

National Action Plan on Climate Change 2008

REC 2010

526 Sugar Mills in operation 2013

Figure /: Chronology of events in bagasse cogeneration in India

Feed-in-tariff fixed by CERC for bagasse cogeneration and RPO fixed by the respective SERC for the year 2013-14 in the bagasse cogeneration states are summarized below in Table

Table 6: Feed-in-tariff fixed by CERC and RPO fixed by the SERC for the year 2013-14

\begin{tabular}{|l|c|c|c|}
\hline \multirow{2}{*}{ State } & $\begin{array}{l}\text { Tariff fixed by CERC in } \\
\text { Rs/KWH [26] }\end{array}$ & Solar & Non solar \\
\cline { 2 - 4 } & 5.40 & 0.25 & 4.75 \\
\hline Andhra Pradesh & 6.13 & 0.10 & 3.00 \\
\hline Haryana & 5.80 & 0.50 & 8.50 \\
\hline Maharashtra & 5.67 & 0.13 & 3.37 \\
\hline Punjab & 5.71 & --- & --- \\
\hline Uttar Pradesh & 4.93 & 0.05 & 8.95 \\
\hline Tamil Nadu & 5.56 & & \\
\hline Others & & & \\
\hline
\end{tabular}

As per CERC tariff order for the year 2013-14, capital cost of the plant is taken as Rs 437.306 Lakh /MW and useful life of plant is taken as 20 years.

The financial assistance is being provided by MNRE for the bagasse cogeneration as capital subsidy for private, cooperative, public sector sugar mills [18]. The BOOT/BOLT projects are being supported in cooperatives/ public sector sugar mills and for the boiler up gradation in existing cooperative sugar mills.

Capital subsidy: Capital subsidy being provided by MNRE is given below in table: 
Table 7: Capital subsidy being provided by MNRE

\begin{tabular}{|c|c|c|}
\hline & $\begin{array}{l}\text { Special Category States(NE Region, Sikkim, } \\
\text { J\&K, HP \& Uttaranchal) }\end{array}$ & Other States \\
\hline $\begin{array}{l}\text { Bagasse Co-generation by Private } \\
\text { sugar mills }\end{array}$ & Rs.18 lakh X( MW $)^{\wedge} 0.646$ & Rs.15 lakh X ( MW)^0.646 \\
\hline \multirow{2}{*}{$\begin{array}{l}\text { Bagasse Co-generation projects by } \\
\text { cooperative/ public sector sugar mills } \\
40 \text { bar \& above }\end{array}$} & Per MW of surplus power & Per MW of surplus power \\
\hline & Rs.40 lakh* & Rs.40 lakh* \\
\hline \multirow[t]{2}{*}{60 bar \& above } & Rs.50 lakh* & Rs.50 lakh* \\
\hline & Rs.60 lakh * & Rs.60 lakh* \\
\hline & \multicolumn{2}{|l|}{ maximum support Rs. 8.0 crore per project } \\
\hline
\end{tabular}

*For new sugar mills, which are yet to start production and existing sugar mills employing backpressure route/seasonal/incidental cogeneration, which exports surplus power to the grid, subsidies shall be one-half of the level mentioned above.

BOOT/BOLT Model :The MNRE has initiated Build, Own, Operate, Transfer (BOOT)/ Build ,Own, Lease , Transfer (BOLT) model cogeneration projects in cooperative/ public sector sugar mills .Central financial assistance for bagasse cogeneration project in cooperative/ public sector sugar mills implemented by Independent Power Producers (IPPs)/State Government Undertakings or State Government Joint Venture Company / Special Purpose Vehicle (Urja Ankur Trust) through BOOT/BOLT model is given below :

Table 8: Support for BOOT/BOLT model

\begin{tabular}{|l|l|l|}
\hline Project Type & Minimum Configuration & Capital Subsidy \\
\hline $\begin{array}{l}\text { Single Cooperative mill through } \\
\text { BOOT/BOLT Model }\end{array}$ & 60 bar \& above & Rs.40 Lakh/MW of surplus power* \\
\cline { 2 - 3 } & 80 bar \& above & Rs.50 Lakh/MW of surplus power* \\
\cline { 2 - 3 } & & *maximum support Rs.8.0 crore/ sugar mill \\
\hline
\end{tabular}

Boiler Up gradation: Central Financial Assistance (CFA) is being extended by MNRE for Bagasse Cogeneration Project in existing cooperative sector sugar mills for boiler up gradation.

Table 9: Support for Boiler up gradation in existing cooperative sugar mill for BOOT/BOLT model

\begin{tabular}{|l|l|l|}
\hline Project Type & Minimum Configuration & Capital Subsidy \\
\hline Existing Cooperative Sugar Mill & 40 bar \& above & Rs.20 Lakh/MW of surplus power \\
\cline { 2 - 3 } & 60 bar \& above & Rs.25 Lakh/MW of surplus power \\
\cline { 2 - 3 } & 80 bar \& above & Rs.30 Lakh/MW of surplus power \\
\hline
\end{tabular}

\section{Barriers toward Cogeneration Deployment in India}

India has made impressive growth in bagasse cogeneration in the last one decade .However sustaining the growth is the real challenge. Further, growth of deployment of bagasse cogeneration has been higher in private sector mills than in cooperatives and public sectors mills. This work has identified the barriers at various levels in the growth of bagasse cogeneration.

The major bottlenecks in harnessing cogeneration potential are:

- Lack of Management Focus: Management does not take cogeneration seriously due to lack of awareness and being busy in solving other problems of sugar mill. In addition, management does not have the competence, particularly in cooperative sugar mills, to establish and run a power plant.

- Financial Constraints: Sugar mills do not have adequate resources to establish cogeneration facility.

- Small Mills: Minimum 2500 TCD capacity is economically viable for establishing cogeneration facility. However older mills in India are smaller in capacity than 2500 TCD.

- Competing Technology: Traditionally bagasse has been used in paper and pulp industry which is still competing technology for the use of bagasse. In some states preferential tariff fixed by SERCs do not account the price offered by the paper and pulp industry to the bagasse.

- Preferential Tariff: As mandated by electricity policy 2006 premium tariff must be fixed for renewable energy by CERC and respective SERCs using cost plus approach. In some states 
preferential tariff fixed by SERCs do not account the higher support price fixed by state government for sugarcane making bagasse cogeneration unattractive.

- Inconsistent RECs: Renewable energy sources are not evenly distributed across Indian states making it difficult for the states not endowed with renewable energy sources to meet RPO and contribute in the growth of renewable energy in the country.REC was adopted in India in 2010 to overcome geographical constraint and provide flexibility to all the states meet RPO .Renewable energy generator can now sell electricity at preferential tariff fixed by SERCs or can sell electricity at average price and environment attribute in the form of REC. $1 \mathrm{MWH}$ of electricity from renewable energy source is equivalent to 1 REC and can be sold to any Discoms across the country . Purchase of the REC by Discom would be counted for the purpose of RPO compliance. However cyclic fluctuation in demand of REC has been observed due to non compliance of RPO by some Discoms and tendency of the Discom to purchase RECs at the time of submission of the RPO compliance status.

- Non compliance of RPO: Certain percentage of electricity, fixed by respective SERC, must be purchased from renewable energy sources by Discoms known as RPO. In addition, Discoms must submit a RPO compliance report to SERC. However there is wide divergence in the RPO fixed by SRECs. Further in the absence of strong RPO compliance mechanism, this instrument has not been able to give desired growth to renewable energy sector.

- Grid Connectivity: Lack of grid connectivity is also a barrier in bagasse cogeneration.

- Unavailability of fuel out of season: Unavailability of fuel out of season is a constraint.

- High wheeling and open access charges in some states : High wheeling and open access charges in some States is also a barrier.

\section{Organizations}

This section provides list of institutions, associations and departments involved in bagasse cogeneration and sugar sector in India to interested readers to gain further insight in the subject.

\subsection{INSTITUTION}

- Vasantdada sugar Institute, Manjri, Pune (http://www.vsisugar.com/ )

- National Sugar Institute, Kalyanpur (http://nsi.gov.in/)

- Sugar Technology Mission, Department of Science \& Technology (Govt. of India) (http://www.tifac.org.in/index1.htm)

\subsection{ASSOCIATION AND DEPARTMENT}

- Indian Sugar Mills Association (ISMA) (http://www.indiansugar.com/)

- National Federation of Cooperative of Sugar Factories Ltd. New Delhi.(http://www.coopsugar.org/ )

- National Cooperative Development Corporation, New Delhi (http://ncdc.nic.in/index.php)

- The Sugar Technologist Association of India ( STAI) (http://www.staionline.org/ )

- CO-GEN Association of India (COGEN INDIA) (http://www.cogenindia.org/default.asp)

- Department of Food \& Public Distribution, (Sugar) (http://www.fcamin.nic.in/dfpd_html/index.asp)

- Department of New and Renewable Energy (http:// www.mnre.gov.in/)

- Central Electricity Regulatory Commission (http:// www.cercind.gov.in/)

- Indian Renewable Energy Development Agency (http:// www.ireda.gov.in/)

\section{Conclusion}

This article has reviewed status of bagasse cogeneration in India comprehensively. As discussed above, India has vast untapped potential of bagasse cogeneration. Further, cogeneration potential will increase in near future. Sugar sector in India is very complex. GOI has taken several initiatives to enhance bagasse cogeneration 
which received positive response from sugar sector. However, this article has indentified the barriers which need to be overcome to continue the growth story.

\section{Reference}

[1] Integrated Energy Policy of GOI, 2006, retrieved from, planningcommission.gov.in/reports/genrep/rep intengy.pdf on 25.11.2013.

[2] Strategic plan for new and renewable Energy sector for the period 2011-17 of MNRE, retrieved from mnre.gov.in/filemanager/UserFiles/strategic_plan_mnre_2011_17.pdf on 2.12.2013

[3] Eleventh plan (2007-12) power capacity addition through grid interactive renewable accessed from http://data.gov.in/dataset/eleventh-plan-power-capacity-addition-through-grid-interactive-renewable-power on 1.12.2013.

[4] Energy Statistics 2013, Ministry of Statistics and Programme Implementation Government of India, New Delhi.

[5] KPMG Report, the Indian Sugar Industry Sector Roadmap 2017, 2007

[6] MNRE website data on installed capacity retrieved from http://www.mnre.gov.in/mission-and-vision-2/achievements/ on 18.12.13.

[7] MNRE Press Release dated 30.08.2013 accessed from http://pib.nic.in/newsite/erelease.aspx?relid=98949 on 03.12.2013

[8] WADE. Bagasse Cogeneration: Global Review and Potential, World Alliance for Decentralized Energy, Edinburgh, 2004.

[9] Ranganathan, M. Can Coops become Energy Producers too? Challenges and Prospects for Efficient Cogeneration in India's Sugar Sector. Master's Project, University of California, Berkeley, CA., 2005.

[10] UNDP. Removal of Barriers to Biomass Power Generation in India, Phase I, 2005.

[11] Barbara Haya, Malini Ranganathan and Sujit Kirpekar, Barriers To Sugar Mill Cogeneration in India: Insights Into The Structure of Post-2012 Climate Financing Instruments, Climate and Development 1 (2009) 66-81

[12] Indian Sugar Mill Association, Data on Sugar production, retrieved from http://www.indiansugar.com/Statics.aspx on 18.12.2013.

[13] Department of Food and Public Distribution GOI, Data on Sugar mills, accessed from http://dfpd.nic.in/?q=node/10 on $\underline{03.12 .2013}$.

[14] Sugarcane production map from Farmer's Portal retrieved from http://farmer.gov.in/cropstaticssugarcane.html.

[15] Rangarajan Committee Report, Regulation of Sugar Sector in India: The Way Forward, 2012.

[16] Indian Renewable Energy and Energy Efficiency Policy Database (IREEED), MNRE, retrieved from www.ireeed.org/statepolicy on 03.12.2013.

[17] Indian Sugar Mills Association, List of Sugar Mills having Cogeneration accessed from website http://www.indiansugar.com/Cogeneration.aspx accessed on 03.12.2013.

[18] MNRE website www.mnre.gov.in/schemes/grid-connected/biomass-powercogen/ accessed on 03.12.2013.

[19] MNRE Annual Report 2012-2013, New Delhi, India retrieved from http://mnre.gov.in/file-manager/annual-report/20122013/EN/chapter3.html.

[20] Natu S C presentation on Biomass Cogeneration Technology in India in INDO-ASEAN Co-operation in Renewable Energy Workshop, November 5, 2012.

[21] Electricity Act 2003, retrieved from powermin.nic.in/acts_notification/electricity_act2003/preliminary.htm on 18.12.2013.

[22] Ministry of Power, National Electricity Policy 2006, New Delhi, India.

[23] National Action Plan on Climate Change, 2008, retrieved from pmindia.nic.in/Pg01-52.pdf on 03.12.2013.

[24] Central Electricity Regulatory Commission (Terms and Conditions for recognition and issuance of Renewable Energy Certificate for Renewable Energy Generation) Regulations, 2010.

[25] Guidelines for Tariff Based Competitive Bidding Process for Grid Connected Power Projects Based on Renewable Energy Sources, December 2012, retrieved from mnre.gov.in/file-manager/UserFiles/.../guidelines_tariff_grid_re.pdf on 03.12.2013.

[26] CERC Order dated 28.02.2013 retrieved from www.cercind.gov.in/2013/orders/SO243.pdf on 03.12.2013. 